University of Nebraska - Lincoln

DigitalCommons@University of Nebraska - Lincoln

Faculty Publications from the Harold W. Manter Laboratory of Parasitology

10-1995

\title{
Proteocephalus chamelensis n. sp. (Cestoda: Proteocephalidae) from the "Guavina" Gobiomorus maculatus (Osteichthyes: Eleotrididae) in Chamela Bay, Jalisco, México
}

\author{
Gerardo Pérez Ponce de León \\ Universidad Nacional Autónoma de México, ppdleon@servidor.unam.mx \\ Daniel R. Brooks \\ University of Toronto,dnlbrooks@gmail.com \\ Reva Berman \\ University of Toronto
}

Follow this and additional works at: https://digitalcommons.unl.edu/parasitologyfacpubs

Part of the Parasitology Commons

Pérez Ponce de León, Gerardo; Brooks, Daniel R.; and Berman, Reva, "Proteocephalus chamelensis n. sp. (Cestoda: Proteocephalidae) from the "Guavina" Gobiomorus maculatus (Osteichthyes: Eleotrididae) in Chamela Bay, Jalisco, México" (1995). Faculty Publications from the Harold W. Manter Laboratory of Parasitology. 287.

https://digitalcommons.unl.edu/parasitologyfacpubs/287

This Article is brought to you for free and open access by the Parasitology, Harold W. Manter Laboratory of at DigitalCommons@University of Nebraska - Lincoln. It has been accepted for inclusion in Faculty Publications from the Harold W. Manter Laboratory of Parasitology by an authorized administrator of DigitalCommons@University of Nebraska - Lincoln. 


\title{
PROTEOCEPHALUS CHAMELENSIS N. SP. (CESTODA: PROTEOCEPHALIDAE) FROM THE "GUAVINA" GOBIOMORUS MACULATUS (OSTEICHTHYES: ELEOTRIDIDAE) IN CHAMELA BAY, JALISCO, MÉXICO
}

\author{
Gerardo Pérez-Ponce de León, Daniel R. Brooks*, and Reva Berman* \\ Laboratorio de Helmintología, Instituto de Biología U.N.A.M., Apartado Postal 70-153, \\ C.P. 04510, México D.F., México
}

\begin{abstract}
A new species of Proteocephalus inhabiting the eleotridid estuarine fish Gobiomorus maculatus is described from Chamela Bay, Jalisco State, Mexico. The new species and $P$. pugetensis are nearly identical in strobila length, presence of a vestigial apical organ, having vaginae only anterior to the cirrus sac, an average of 4-7 uterine diverticula per proglottis, and a ratio of cirrus sac length to proglottis width averaging approximately 1:4. Proteocephalus pugetensis differs from the new species by having an average of 35 rather than 68 testes per proglottis, vitelline follicles terminating posteriorly at the level of the anterior margin of the ovary rather than at the level of the posterior margin, and equatorial genital pores rather than genital pores located in the anterior $1 / 4$ of the proglottis. Finally, Proteocephalus pugetensis occurs from estuarine habitats along the Pacific coast of the United States; the new species was collected from an estuarine habitat on the Pacific coast of México.
\end{abstract}

During an inventory of the helminth parasites of marine and brackish fishes from Chamela Bay in the state of Jalisco on the west coast of México, an undescribed species of Proteocephalus Weinland, 1858 was collected. We describe that species herein.

\section{MATERIALS AND METHODS}

In August 1993, 2 specimens of Gobiomorus maculatus (Günther, 1859) Eigenmann and Eigenmann, 1941 (local name guavina) were collected by fishermen using gill nets in the Estero Chamela, which is located in Chamela Bay on the Pacific coast of México. Cestodes were relaxed in hot tap water $(80 \mathrm{C})$; some were fixed in $10 \%$ formalin for cross sections and some were fixed with Bouin's fluid with slight coverglass pressure for whole mounts. They were stored in $70 \%$ ethanol, stained in Mayer's paracarmine and Harris' hematoxylin, cleared in methyl salicylate, and mounted in Canada balsam. Cross sections cut at $7 \mu \mathrm{m}$ were stained with hematoxylin-eosin. All measurements are in micrometers unless otherwise stated, with the range followed by the sample measure, and the mean and standard deviation in parentheses. Illustrations were made with the aid of a camera lucida.

\section{DESCRIPTION \\ Proteocephalus chamelensis n. sp. (Figs. 1-5)}

The description is based on measurements from 15 specimens: Strobila $15-57 \mathrm{~mm}(\mathrm{n}=8 ; \bar{x}=34.8 \pm 16.4)$ long. Scolex aspinose, $737-$ $1,375(\mathrm{n}=15 ; \bar{x}=916 \pm 182)$ wide, with vestigial glandular apical organ, ventral longitudinal incision, and 4 shallow suckers. Suckers $312-$ $437(n=30 ; \bar{x}=371 \pm 31)$ long by $250-300(n=30 ; \bar{x}=277 \pm 19)$ wide. Immature proglottides wider than long, 137-450 $(\mathrm{n}=15 ; \bar{x}=$ $295 \pm 94)$ long by $850-1,425(n=15 ; \bar{x}=1,081 \pm 198)$ wide. Ratio of proglottis length to width $1: 2.12-5.68(\mathrm{n}=15 ; \bar{x}=1: 3.73)$. Mature proglottides $200-587(\mathrm{n}=15 ; \bar{x}=363 \pm 157)$ long by $1,062-2,162(\mathrm{n}$ $=15 ; \bar{x}=1,301 \pm 401)$ wide. Ratio of proglottis length to width $1: 1.9$ $6.9(\mathrm{n}=15 ; \bar{x}=1: 4.17)$. Testes medullary, in 2 indistinct fields, 55-81 $(\mathrm{n}=15 ; \bar{x}=72 \pm 12$ per proglottis) in number, averaging 10 preporal, 22 postporal, and 33 aporal, $40-50$ in diameter $(n=30 ; \bar{x}=45 \pm 4)$. Cirrus sac elongate, $250-462(n=15 ; \bar{x}=345 \pm 80)$ long and 120-207 ( $n=15 ; \bar{x}=150 \pm 40$ ) wide, containing ejaculatory duct and cirrus; ratio of cirrus sac length to mature proglottis width $1: 3.2-5.0(n=15$; $\bar{x}=1: 3.79$ ). Vas deferens coiled. Genital pore alternating irregularly in

Received 12 September 1994; revised 28 April 1995; accepted 28 April 1995.

* Department of Zoology, University of Toronto, Toronto, Ontario, Canada M5S 1A1. anterior $22-26 \%(n=15 ; \bar{x}=25 \%)$ of proglottis. Vagina anterior to and never crossing cirrus sac, with muscular sphincter. Ovary medullary, bilobed, 560-970 $(\mathrm{n}=15 ; \bar{x}=743 \pm 114)$ wide; lobes $125-275(\mathrm{n}=$ $20 ; \bar{x}=213 \pm 35$ ) long. Uterus medullary, preformed in mature proglottis. Vitelline follicles medullary, extending from near posterior end of proglottis to slightly anterior to vaginal level, occupying $80-87 \%$ of proglottis length and situated in dorsal position in transverse sections; $16-32$ in diameter $(\mathrm{n}=30 ; \bar{x}=25 \pm 6)$. Gravid proglottides 560-970 $(\mathrm{n}=15 ; \bar{x}=730 \pm 134)$ long by $1,800-2,110(\mathrm{n}=15 ; \bar{x}=1,500 \pm$ 283) wide; ratio of proglottis width to length $1.30-3.70(\mathrm{n}=15 ; \bar{x}=$ $1: 2.11)$. Testes degenerating, fewer in number than in mature proglottides. Uterus with 3-7 $(n=13 ; \bar{x}=5 \pm 1)$ lateral diverticula on each side. Embryophore $19-25(n=50 ; \bar{x}=20 \pm 4)$ long by $12-16(n=50$; $\bar{x}=14 \pm 2$ ) wide.

\section{Taxonomic summary}

Host: Gobiomorus maculatus (Günther, 1859) Eigenmann and Eingenmann, 1891, "guavina" (Osteichthyes: Teleostei: Eleotrididae).

Site of infection: Small intestine.

Type locality: Estero Chamela, Bahía de Chamela, 19³0', 19³2' latitude $\mathrm{N}$ and $105^{\circ} 06^{\prime}$ longitude W. Jalisco State, west coast, México.

Prevalence: One hundred percent (2/2, with 39 and 19 specimens).

Specimens deposited: Holotype: Colección Helmintológica. IBUNAM No: Mexico II-333. Paratypes: USNPC No. 84880, Colección Helmintológica IBUNAM México Nos: II-334-335 and the Museum de Historie Naturelle de Geneve, Switzerland No. INVE 18256.

Etymology: The new species is named for the type locality.

\section{DISCUSSION}

The genus Proteocephalus Weinland, 1858, which includes more than 170 nominal species with a worldwide distribution (Schmidt, 1986), and the family Proteocephalidae La Rue, 1911 have been the subject of a number of taxonomic reviews (La Rue 1911, 1914; Freze, 1965; Brooks, 1978a, 1978b; Chambrier, 1989a, 1989b). Recently, García-Prieto (1993) examined the status of 97 nominal species of Proteocephalus reported from the Americas as parasites of fishes, amphibians, and reptiles, considering only 57 of them valid.

In México, 7 species of Proteocephalus have been reported previously: Proteocephalus singularis La Rue, 1911 from the fish Lepisosteus tropicus Gill, 1863 in Tabasco by Osorio et al. (1987); Proteocephalus pusillus Ward, 1910 from the fish Goodea atripinnis Jordan, 1880 in Michoacán by Mejía (1987); Proteocephalus filaroides La Rue, 1909 by García-Prieto (1986) in the salamander Ambystoma tigrinum Green, 1825 in the state 

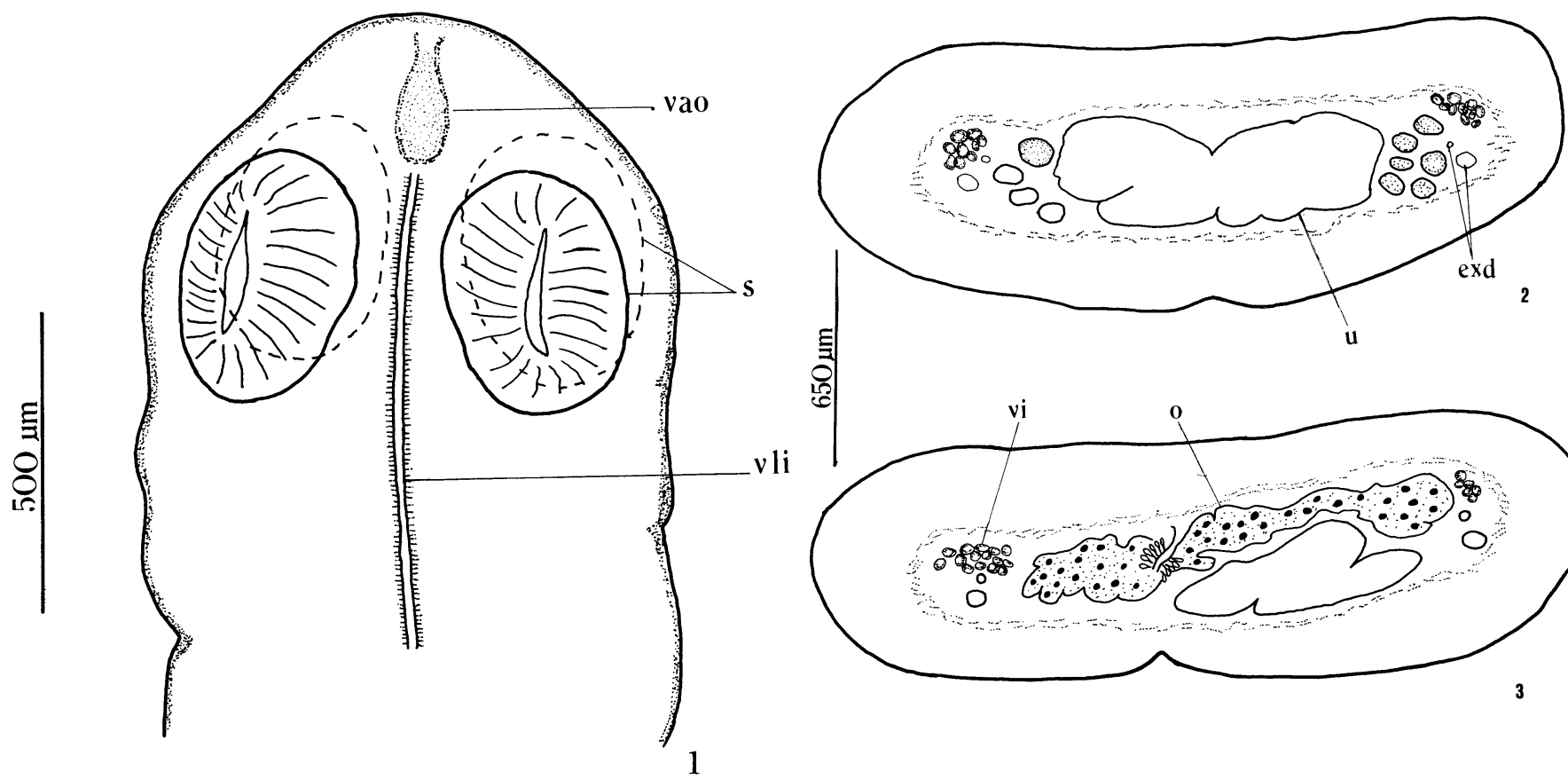

$v$ li

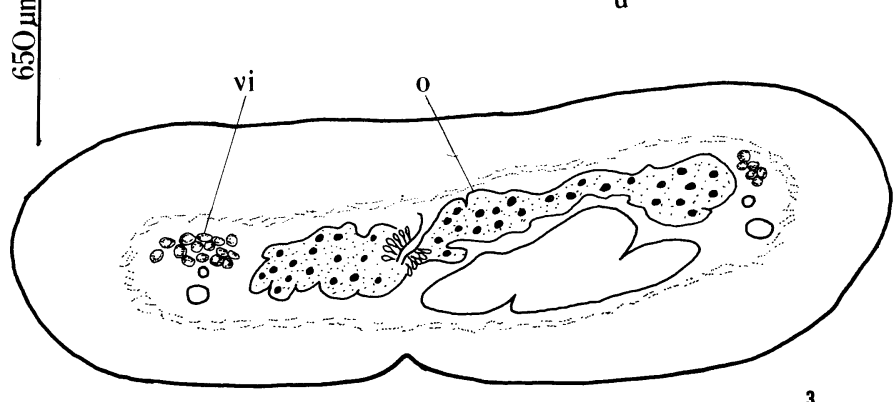

Figures 1-5. Drawings of Proteocephalus chamelensis n. sp. 1. Scolex. 2, 3. Cross sections of gravid proglottides showing the medullary position of vitelline follicles and testes. 4. Mature proglottis. 5. Gravid proglottis; cp, cirrus pouch; exd, excretory duct; eyd, ejaculatory duct; o, ovary; pu, preformed uterus; s, suckers; t, testes; u, uterus; v, vagina; vao, vestigial apical organ; vd, vas deferens; vi, vitellaria; vli, ventral longitudinal incision.

of México, and by Pulido (1994) in the frog Rana dunni Zweifel, 1957 from Michoacán; Proteocephalus racemosus (Rudolphi, 1819) La Rue, 1911 by Cruz (1974) in the snakes Thamnophis macrostemma Kennicott, 1860 and Thamnophis melanogaster Peters, 1864 in the states of México, Michoacan, and Federal District; Proteocephalus perspicua (La Rue, 1911) Harwood, 1933 in the snake Thamnophis erythrogaster Hallowell, 1852 in Nuevo Leon by García Prieto (1986); Proteocephalus micruricola Shoop and Corkum, 1982 described from the snake Micrurus diastema affinis Jan, 1858 in the state of Oaxaca; and, finally, Proteocephalus nattereri Parona, 1901 described by Flores Barroeta (1955) from a "culebra roja" (red snake) in the state of Chiapas. García-Prieto (1993) considered P. micruricola a species inquirenda because the original description did not include a description of the position of the gonads in cross section, which is necessary to justify the inclusion of specimens in the family Proteocephalidae. Of those species, $P$. chamelensis is somewhat similar to $P$. perspicua and $P$. filaroides by having a vestigial apical organ but differs by having vaginae that open only anteriorly to the cirrus sac rather than anteriorly or posteriorly and in having a mean number of testes per proglottids of 68 rather than more than 200; in addition, $P$. perspicua is a parasite of freshwater snakes and $P$. filaroides is a parasite of amphibians.

Among American species of Proteocephalus recognized by García-Prieto (1993), 29 have an average of fewer than 100 testes per proglottis. Nine of those possesses vestigial apical organs similar to that found in P. chamelensis: Proteocephalus ambloplitis (Leidy, 1887) Benedict, 1900; Proteocephalus amphiumicola Brooks, 1978; Proteocephalus australis Chandler, 1935; Proteocephalus buplanensis Mayes, 1976; P. filaroides La Rue, 1909; Proteocephalus paralacticus MacLulich, 1943; Pro- teocephalus pugetensis Hoff and Hoff, 1929; Proteocephalus sireni (Brooks and Buckner, 1976) Brooks, 1978; and Proteocephalus tumidicollis Wagner, 1953. Proteocephalus chamelensis appears to be most similar to $P$. buplanensis and $P$. pugetensis because all 3 possess $4-7$ uterine diverticula on each side. The other 7 species have more than 11 uterine diverticula on each side and much longer strobilae.

Proteocephalus chamelensis differs from $P$. buplanensis by having vitelline follicles extending posteriorly to the posterior margin of the ovary rather than terminating at the anterior margin and by having vaginae that are anterior rather than dorsal to the cirrus sac. Proteocephalus buplanensis also inhabits a cyprinid fish (Semotilus atromaculatus) in freshwater systems of Nebraska (Mayes, 1976), whereas P. chamelensis inhabits an eleotridid in estuarine habitats of México. Proteocephalus chamelensis is very similar to $P$. pugetensis and is perhaps closely related to it. The species are nearly identical in strobila length, presence of a vestigial apical organ, anterior position of the vaginae, number of uterine branches (4-7), and ratio of cirrus sac length to proglottid width (averaging 1:4), but $P$. pugetensis differs from $P$. chamelensis by having an average of 35 rather than 68 testes per proglottis, vitelline follicles terminating posteriorly at the level of the anterior margin of the ovary rather than at the level of the posterior margin, and equatorial genital pores rather than genital pores located in the anterior $1 / 4$ of the proglottis. Proteocephalus pugetensis was collected in the gasterosteid fish Gasterosteus cataphractus (=aculeatus s.l.) from estuarine habitats along the Pacific coast of the United States (Seattle) (Hoff and Hoff, 1929); the type locality for $P$. chamelensis is also a brackish water habitat along the Pacific coast of México.

Among species of Proteocephalus worldwide, Proteocephalus 

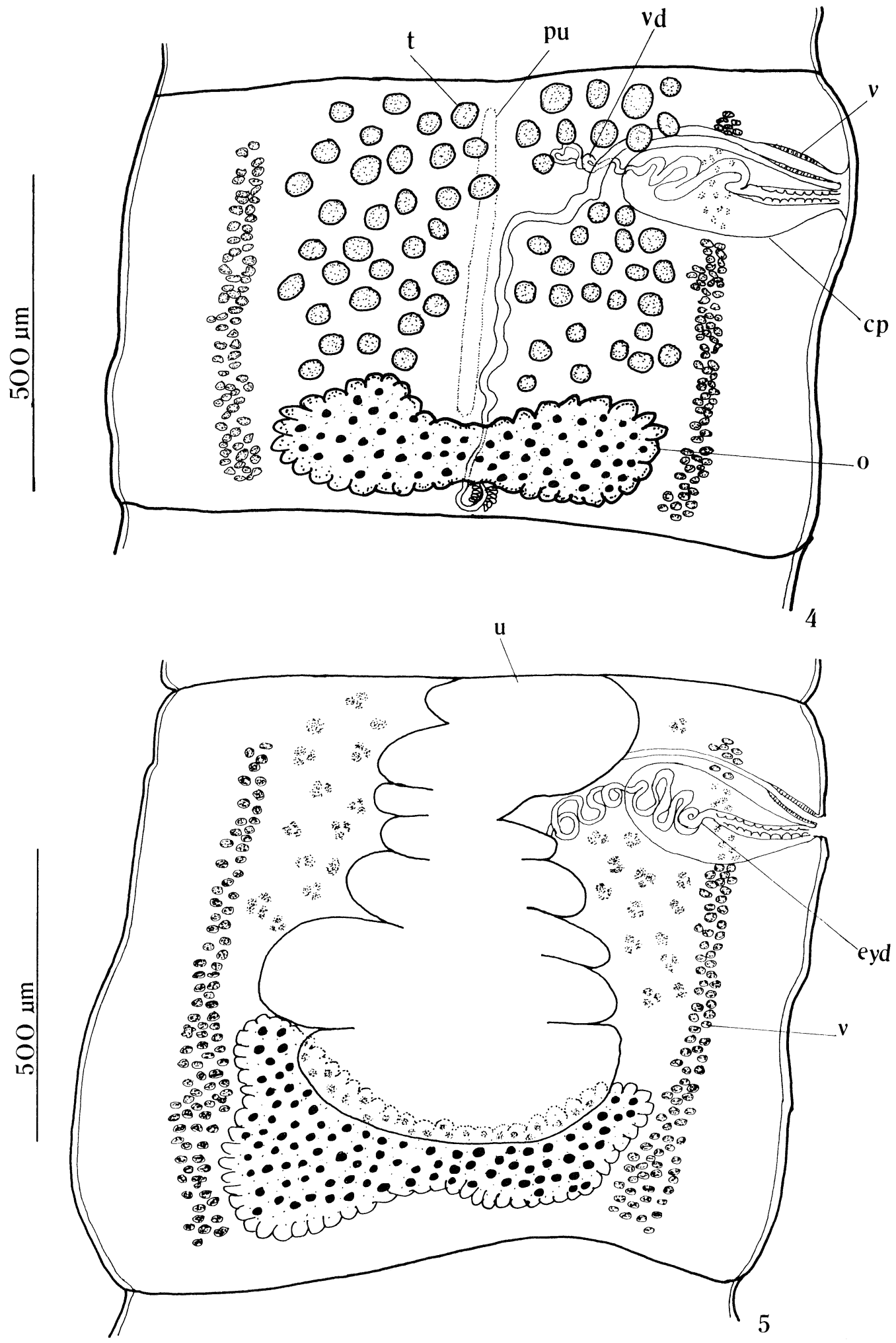

filicollis (Rudolphi, 1802) Weinland, 1858, Proteocephalus laruei Faust, 1919, Proteocephalus luciopercae Wardle, 1932, and Proteocephalus ptychocheilus Faust, 1919 share the following 3 traits with $P$. chamelensis: an average of 4-7 uterine diverticula in each side, an average of approximately 70 testes per proglottis, and vaginae opening anteriorly to the cirrus sac only. They differ from the new species, however, by lacking apical suckers or organs, having vitelline follicles that terminate posteriorly at 
the anterior border of the ovary, and having equatorial or postequatorial ( $P$. filicollis) genital pores (see Freze, 1965).

\section{ACKNOWLEDGMENTS}

The field work was done in the Estacion de Biologia Chamela. We thank the following people for invaluable help in fieldwork: Luis Garcia, Griselda Pulido, Berenit Mendoza, Virginia León, Maribel Garzón, Patricia Ramos, Ma. Antonieta Arizmendi, and Elizabeth Castillo. We thank Luis García for reviewing and commenting the manuscript. Funds for this research were provided by Programa de Apoyo a Proyectos de Investigación e Inovación Technológica PAPIIT-UNAM No. IN201593 to G.P.P.L. and NSERC operating grant A7696 to D.R.B.

\section{LITERATURE CITED}

BROOKs, D. R. 1978a. Systematic status of proteocephalid cestodes from reptiles and amphibians in North America with descriptions of three new species. Proceedings of the Helminthological Society of Washington 45: 1-28.

. 1978b. Evolutionary history of the cestode order Proteocephalidea. Systematic Zoology 27: 312-323.

ChAmbrier, A. DE. 1989a. Révision du genre Crepidobothrium Monticelli, 1900 (Cestoda: Proteocephalidae) parasite d'ophidiens néotropicaux. I. C. gerrardi (Baird, 1860) et C. viperis (Beddard, 1913). Revue Suisse de Zoologie 96: 191-217.

. 1989b. Révision du genre Crepidobothrium Monticelli, 1900 (Cestoda: Proteocephalidae) parasite d'ophidiens néotropicaux. II. C. dollfusi Freze, 1965, C. lachesidis (MacCallum, 1921) et conclusions. Revue Suisse de Zoologie 96: 345-380.

CRUz, R. A. 1974. Primer registro y redescripción de Ophiotenia racemosa (Rudolphi, 1819) La Rue, 1911 recolectada en dos especies de colúbridos de México. Anales Instituto de Biología Universidad Nacional Autónoma de México Serie Zoologia 45: 51-64.
Flores Barroeta, L. 1955. Céstodos de Vertebrados I. Ciencia 13: 31-36.

FreZE, V. I. 1965. Essentials of cestodology Vol. V. Proteocephalata in fish, amphibians and reptiles. Izdat. Akad. Nauk., Moscow, Israel Program for Scientific Translations, Jerusalem, 1969, 597 p.

García-Prieto, L. 1986. Estudio taxonómico de algunos céstodos de vertebrados de México. Tesis Profesional. Universidad Nacional Autónoma de México, México, $75 \mathrm{p}$.

- 1993. Análisis del estado taxonómico de las especies americanas del género Proteocephalus Wienland, 1858, (Cestoda: Proteocephalidea). Tesis de Maestría. Universidad Nacional Autónoma de México, México, 128 p.

HoFf, E., AND H. E. HofF. 1929. Proteocephalus pugetensis, a new tapeworm from a stickleback. Transactions of the American Microscopical Society 48: 54-61.

LA Rue, G. 1911. A revision of the cestode family Proteocephalidae. Zoologischer Anzeiger (Leipzig) 38: 473-482.

- 1914. A revision of the cestode family Proteocephalidae. Illinois Biological Monographs 1: 1-350.

MAYes, M. A. 1976. Proteocephalus buplanensis sp. n. (Cestoda: Proteocephalidae) from the creek chub, Semotilus atromaculatus (Mitchill), in Nebraska. Proceedings of the Helminthological Society of Washington 43: 34-37.

Mejí, M. H. 1987. Helmintofauna del "tiro" Goodea atripinnis Jordan, 1880, en el Lago de Pátzcuaro, Michoacán. Algunas consideraciones ecológicas de las poblaciones de helmintos en sus hospederos. Tesis de Profesional. Universidad Nacional Autónoma de México, México, 122 p.

Osorio, S. D., R. Pineda, AND G. Salgado. 1987. Fauna Helmintológica de peces dulceacuícolas de Tabasco. Estudio preliminar. Universidad y Ciencia 4: 5-31.

Pulido, F. G. 1994. Helmintos de Rana dunni Zweifel, 1957, especie endémica del Lago de Pátzcuaro, Michoacán, México. Anales Instituto de Biología Universidad Nacional Autónoma de México. Serie Zoología 65: 205-207.

SCHMIDT, G. D. 1986. Handbook of tapeworm identification. C.R.C Press, Boca Raton, Florida, 675 p. 